\title{
The Effect of Using Educational Drama on Developing Speaking Skill of the Sixth Graders in the English Language
}

\author{
Ahmad Issa Altweissi, Razan Yaseen Maaytah ${ }^{2}$
}

\begin{tabular}{l} 
ARTICLE INFO \\
\hline Article History: \\
Received 10.01.2021. \\
Received in revised form \\
01.08 .2021$. \\
Accepted \\
01.01.2022
\end{tabular}

\begin{abstract}
For the purpose of study, drama lessons were implemented through a selected unit of the English textbook for an experimental group of the sixth grade, compared with teaching the same units by employing the conventional teaching method for the control group. The study uses the quasiexcremental approach to collect data via a designed oral pre-test and post-test consisted of (13) questions, and students' attitude questionnaire consisted of (35) items distributed over four main domains. The study sample includes (70) students divided into two groups; experimental and control consists of (35) students for each. The results of the study revealed that the application of drama teaching method had positively influenced English language speaking outcomes. In addition, the results showed that the use of drama activities technologies opens the opportunity to support English language speaking skills with advantages over conventional teaching patterns. Moreover, results of the study confirmed that the students developing a positive attitude when adopting dram classes and can improve their students' performance. Finally, the study recommended developing and including the dram activities in teaching English speaking and other English learning skills.
\end{abstract}

(CTUARA Journal. All rights reserved

Keywords: ${ }^{1}$

Drama, speaking skill, sixth graders, English language, attitudes

\section{INTRODUCTION}

English language is considered as one of the most used languages around the world, where its importance related to its role, which goes to its use as a common universal language in the world. Thus, English language is taught at every school in Jordan, with the aims to enable students to learn basic language skills: listening, speaking, reading, writing, and helping them acquire learning curricula. Within the Jordanian context, there is an assumption that the teaching of speaking skill in Jordanian schools still based on conventional methods, where the teacher controls and directs the learning process, while the role of the learner is negative (Al-Jamal and Al-Jamal, 2014). The speaking skill depends not only on the proficiency of the learners of the structures and language versions only, but also requires their understanding of other things related to how to use those structures in the appropriate situation (Duman \& Karagoz,2016; Karagöz \& Ruzgar, 2020).

As reported by Ali (2008), educational drama is a practical application of unconventional teaching method. In particular, that educational drama challenges students' abilities and aptitudes, and provides them with a safe environment to develop their speaking skills and understand others in new ways using body, mind, language and emotions. Modern learning theories emphasize activity-based learning such as the constructivist theory, which focuses on learning, not education. The importance of the constructivist theory crystallized in building knowledge among students from experiences to find solutions to the present and refine expectations and challenges for the future (Zaitoun, 2007). Constructivist theory based on

principles,

${ }^{1}$ Mutah University/Faculty of Educational Sciences, a-towisi@mutah.edu.jo. orcid.org/0000-0003-3566-4053

${ }^{2}$ Ministry of Education/JORDAN. razan.zezozezo@gmail.com. orcid.org/0000-0001-8975-0956 
the first principle related to the that knowledge is not passively transmitted to the individual, but rather builds his own understanding in an active manner, while the second principle related to the individual perception, which needs to be adoptive and could learn through an experiential context. Therefore, the design of drama activities can support these principles since students can retain and build new knowledge through an experimental context with dramatic activities (Rabab'a, 2015).

The method of educational drama is one of the modern methods that can be followed in language learning, it is believed to be an effective method that employs student activity and helps them to learn through playing different roles. It is expected through drama the learner uses all his senses and energy to discover the information himself or with the help of his colleagues away from direct indoctrination (Nassar, 2000). The drama, including its representative experiences, is a very deep and rich input, if it is perceived to be used in the formation of educational experiences. It is a way for students to learn it in their own way using their movements and their voices.

To sum up, it can be concluded that using educational drama could contribute to an active learning process where students can use a set of drama strategies, including role playing, storytelling, voice and speech. Accordingly, and based upon the previous discussions, it is expected that the current study spot the light on the effect of using dramatic activities in teaching EFL and its potential effect on enhancing students speaking skills. Thus, the qusai-experimental approach employed to figure out the drama effect on students' achievement and students' attitude toward learning the English language.

\section{Problem Statement}

Through the work of the researchers in the field of education; as an English language teacher and as educator, they noticed that there is a weakness on the students' speaking skill in English, especially those students in the primary stage. This situation, in many aspects could be attributed to the use of traditional methods of teaching English language (Al-Sharary, 2019; Attia, 2015; Ali, 2012). Therefore, teachers are required to find alternative methods to develop speaking skill, such as using drama as a teaching method. Thus, how to develop speaking skills by employing drama as a teaching method forms the key question of the current study. In other words, there is a need to investigate the effect of using drama activities on developing oral speaking skills among the sixth-grade students in the schools of Al-Karak Educational Directorate and their attitudes toward English language learning.

\section{Study Questions}

Based on the key question that formulates the study problem and background, the following subquestions were formulated:

1. Are there any statistically significant differences at the level of $(\alpha=\leq 0.05)$ in the development of the sixth-grade students speaking skill attributed to the teaching method (drama, conventional)?

2. Are there any statistically significant differences at the level of $(<=0.05)$ in the development of speaking skill attributed to the variable of student gender (males, females)?

3. Are there any statistically significant differences at the level of $(\alpha=\leq 0.05)$ in developing the attitude of the $6^{\text {th }}$ graders toward learning English that could be attributed to the teaching method (drama, conventional) or to gender (male, female)?

\section{Significance of the Study}

The Significance of the current study relates to several issues, among which are the following:

1. The importance of encouraging the use of drama strategy to suit the age of students

2. Directing the attention of those who teach English on how to develop the speaking skill of $6^{\text {th }}$ grader using the activities as a teaching method.

3. Drawing the attention of all the stakeholders involved in the learning process of speaking skill because it has a significant impact on learning English.

4. Drawing attention of the educators how positive attitude towards the language can lead to increased motivation and better learning achievement.

\section{Limitations of the study}

The study was limited to the following:

1. Objective Limitations: The current study aims at investigating the effect of educational drama on the development of $6^{\text {th }}$ graders' speaking skills and their attitudes toward learning the English language.

2. Time limitations: This study conducted in the $2^{\text {nd }}$ semester of the academic year 2019/2020. 
3. Spatial limitations: This study conducted on two schools in Karak Directorate of Education, namely, and Al Mansheya Secondary School for Girls, and Al Mansheya Secondary School for Boys.

4. Sample limitations: This study limited to the $6^{\text {th }}$-grade students in Karak directorate of education.

\section{Theoretical Background}

\section{Origins of Educational Drama:}

The drama is a Greek word derived from the ancient Greek verb (Daro) or (Dromenon), which means performing activities whether in life or on stage. Drama concepts can be viewed as a simulation of human action as people from childhood stage have the instinct for diagnosis, simulation, and role-play, and through this instinct, they learn the lessons of life (Kauts, 2016). Within the same context, Kalogirou et al. (2019) defined educational drama as learner imagines himself as another person located elsewhere and expresses a specific role using his body or language skills to communicate with others in a meaningful way in a creative learning medium. Drama increases the learner's self-confidence and encourages his/her imagination and abilities to interact and communicate with the community where s/he lives in.

Moreover, educational drama can be viewed as subject and medium for education based on knowledge practicing context in which the student unites with a role in a situation for discovering and learning through the dramatic experience (Maiullo, 2018). Thus, teachers can use educational drama as a creative tool in many educational purposes due to its effective ability to demonstrate and refine the skills and abilities of the child through playing roles and embodying various dramatic situations that lead him to uncover and express using his tools. The dramatic event is a representative activity that the teacher and students perform using drama strategies where the student united play an appropriate role in his real personality, learning multiple skills such as analysis and criticism, thus, drama develops his/her language skills, emotional and linguistic perceptions (Revathy \& Ravindran, 2016).

\section{Drama in Education}

The use of drama in the educational context can refine the personality of the learner; hence, its importance is not evident only by playing and entertainment, but also by developing the learner's manual skills such as drawing, singing and acting through representative play and role-playing. Drama helps to develop student's perceptions in understanding concepts and enjoy the values of conditions that are around, contribute to achieve educational goals such as physical health, developing scientific and mental capabilities, developing values, and preparing the individual to be active in his community. Therefore, teachers called for adopting the integration of drama arts in the curriculum due to its educational role and importance in the development of knowledge and skills among school students that gives students leadership in the learning process (Ali, 2012).

\section{Education Drama strategies}

Drama strategies are the tools and techniques employed by teachers in dramatic arts. These strategies are used to explore a theme, text or idea while engaging students in the creative process. Implementing drama strategies encourages students to build inquiry skills and explore their imagination for understanding. Through drama strategies, students enhance their teamwork, character development, storytelling, and performance skills. Drama strategies can be used across the curriculum and require students to be actively engaged in their learning.

Drama strategies are tools and methods used by teachers in performing arts. These strategies are applied to explore a trait, text, or impression while charming students in the imaginative process. Applying drama strategies inspires students to figure exploration skills and discover their imagination for consideration. Using drama strategies boost student's cooperation, personality development, storytelling, and presentation skills. Drama strategies can be used in curricula and need students to dynamically participate in their learning process (Moore, 2004).

The drama strategy is one of the teaching approaches that help to enrich and deepen the learning process, given its link to the direct experience resulting from the activity and effectiveness of the learner. The strategy helps achieve many goals that may be difficult to achieve through traditional teaching methods. The classifications of educational drama have multiplied, and perhaps the most important classifications as a method based on converting some textbook content into dramatic activities. Students are trained to physically reincarnate their roles so that the teacher during the training and after the performance will provide the students with the appropriate feedback (Al-Kokhn and Haniyeh, 2009). In addition, it helps to 
organize the educational content of a subject in practical situations, focusing on the important elements and ideas to be communicated, and the students represent the roles involved in the situations under the supervision of the teacher. A dramatic activity that is performed inside or outside the classroom includes the use of several art activities and media to communicate specific educational concepts and goals. Therefore, it involves a role-playing process, in which a person has a dramatic look as it happens, it is also done by converting boring concepts into attractive ones (Kauts, 2016). Based on the role of educational drama, it can be said that educational drama is an educational learning strategy used in teaching. It depends on providing the educational material for students through the representative performance that does not emerge through the actual reincarnation of the characters. In addition, it combines the performance of the various movements of the body parts with the spoken language.

To sum up, it can be claimed that educational has a prominent and active role in language teaching and learning in general, and particularly in speaking. Actually, a variety of dramatic activities can be used, such as acting, role-playing and improvisation. Furthermore, educationists emphasize the necessity of employing drama in language learning and teaching it in the classroom due to its immense role in achieving some learning outcomes, such as learning vocabulary, new linguistic and grammatical structures, reducing language errors, and language acquisition through active communication according to a realistic context (Kempe, 2003).

The researchers reviewed studies that discussed the effect of using drama in teaching English language, several were consulted among which are the following: Stinson (2004) investigates the effect of using drama as a learning strategy for $10^{\text {th }}$ graders in developing their communicative skills. The intervention included the planning of dramas, the training of facilitators and the implementation of ten lessons. A pre- and post-speaking examination was administered to 140 students who were chosen randomly 70 each for both the intervention and control groups Data was collected via pre and post-tests for randomly selected students from the intervention and control groups, facilitators' journals, the interviewing of facilitators, and the students' regular English teachers. The findings indicated that a program of process drama interventions produced enhanced results in participating students' oral communication scores. Furthermore, students and teachers identified improvements in the motivation and self-confidence of participants, as well as indications of enhanced inter-group relationships and communication across ethnicities. Janudom and Wasanasomsithi (2009) examine the benefits of drama and questioning on communicative skills. The attitudes of students towards English instruction employing such techniques were also investigated. The study was conducted with an intact group of 15 students; three males and 12 females, who were second-, third-, and fourth-year students enrolled in an elective course offered by the university as a seven-week English through Drama Summer Course. A speaking achievement pre- and post-tests were administered to collect the data. Also, a teacher's diaries, student's journals and attitude questionnaires were conducted as data collection instruments to investigate the students' attitudes towards the instruction using drama and questioning techniques. Research findings revealed that drama and questioning techniques were effective for the enhancement of speaking abilities. Results suggested that students benefited from drama and questioning techniques. Moreover, their positive attitudes towards the English instruction delivered through the integration of drama and questioning techniques yielded further support to the effectiveness of these two techniques. Rabab'a (2015) investigates the impact of using educational drama for learning the speaking skill. The study comprised a sample of (ASOL) students in the Language Center-University of Jordan. The sample consisted of (47) students in two sections, the first represented the experimental group that studied through the educational drama, and the second represented the control group that studied through the traditional method. The study showed that there are a statistically significant difference in the mean scores of the two groups in favor of the experimental group, it also showed no difference in the two groups as per using the students of (ASOL). Helwa (2015) identifies that the impact of using puppets to enhance listening and speaking skills between primary school students. The study sample consisted of (30) male and female students in Al-Hessa Primary School for Girls and Boys in Qalyubia Governorate, Egypt. The research relied on the semi-experimental approach based on dividing the sample members into two experimental and control groups to be tested later. Results revealed the use of doll-based learning resulted in statistically significant differences for the benefit of the experimental group. Sarmento and Messac (2017) discovers the developed speaking skill using drama for second-grade students at Escola Tekniku 
Vocational School in Oe-cusse in the 2017 academic year. Based on the result of the research, it has been found that there has been an improvement in students' speaking skill after carrying out English teaching using drama. The process of teaching and learning to speak English using the drama method was going smoothly and most students were excited. This drama strategy is not challenging for students, but it can be considered one of the fun activities for students in the classroom teaching and learning process. MasoumiMoghaddam (2018) explores the contexts in which techniques and practices of drama can be performed, as they are implemented in English language classes alongside educational practices to teach and learn English conversation. He figured out the appropriate conditions that enhance the educational environments helping to learn English language conversations using dram. Participants in this study were thirty undergraduate students who studied English at the secondary levels in public schools in Ardabil. They are classified into two groups including control and experimental groups. The two groups were exposed to test and retest to measure the target language skills that would be taught to them. After analyzing the data, the results showed that there was no significant improvement in the English language proficiency of the control group, but the experimental group revealed enormous achievements in their abilities in English conversations using dramatic speech. Susanti (2019) verifies the effectiveness of using drama techniques in teaching the difficult units of the EFL course about developing language proficiency and reducing the level of anxiety of middle school students. The study adopted a semi-experimental design (experimental/control). The sample of the study consisted of $(\mathrm{N}=48)$ from the first intermediate grade students. The experimental group consisted of $(\mathrm{N}=23)$, in which difficult units were taught through drama techniques. The control group consisted of $(\mathrm{N}=$ 25) where the difficult units were taught by traditional methods. The results indicated the positive effects of using drama techniques to develop language proficiency and reduce the level of anxiety among intermediate school first graders. The study found that the drama Techniques facilitates the teaching of the challenging modules of the EFL course for students and encourages English language supervisors and teachers to use the existing teaching strategy that makes students participate and stimulate their thinking and abilities. It helps students direct their attention with teachers because teaching through new methods such as drama is very interesting. It can be concluded that most of the previous studies, which address drama-teaching methods such as Masoumi-Moghaddam (2018) and Susanti (2019) have used two groups: experimental group and control group. In all these studies, the experimental group outperformed the control groups. However, none of them investigates students' attitude toward English language teaching. Moreover, the uniqueness of the current study stems from the reality that it will be the first within its context as it has been conducted in schools of Karak Directorate of Education.

\section{Methodology and Research Design}

Within this part of the study, the used research methodology, sample, instruments, and data collection are presented. In addition, it presents the research design including the pilot study, the field study, instruments validity and reliability and data analysis techniques.

\section{Methodology}

This research employed the quasi-experimental approach using a pre-posttest on equivalent control and experimental groups to explore the effect of employing dramatic lessons on English language for $6^{\text {th }}$ graders in the schools of the Karak Education Directorate.

In this research, two groups were chosen randomly: a control group, which was taught using the conventional teaching method, and an experimental group, which was taught the same content by employing educational drama. A pretest in English language for $6^{\text {th }}$ graders was administered to both groups to measure student's achievement before the experiment. The same test was administered as a posttest to both groups before and after at the end of the dramatic lessons to explore the differences between the study groups. Moreover, a self-completed questionnaire was employed to measure students' attitudes toward the English language where it was administered to both groups, before and after the experiment as shown in the diagram of the study's design. 
Diagram of the Study's Design

\begin{tabular}{ccc}
\hline $\begin{array}{c}\text { Group } \\
\text { Experimental Group }\end{array}$ & $\begin{array}{c}\text { Pre-test } \\
\text { and }\end{array}$ & $\begin{array}{c}\text { Drama Teaching } \\
\text { Method }\end{array}$ \\
Control Group & Pre- attitude Scale & $\begin{array}{c}\text { Post-test } \\
\text { and } \\
\text { Conventional } \\
\text { Teaching Method }\end{array}$ \\
\end{tabular}

\section{Drama Activities Lessons}

To achieve the study objective, the unit of "At the book fair" in action pack (6) was chosen including (3) lessons; lesson (1): ask and answer 1, lesson (2): ask and answer 2 and lesson(3): ask and answer 3. These lessons were chosen purposefully because they were suitable for using dram activities since they contained events and situations that could be mapped to dramatic scenes. The learning contents of these lessons were taught to the experimental group through drama activities. These lessons and the associated drama activities were validated by a panel of teaching instructions experts. Thus, some modifications were made based on the results of the pilot study to produce the final version of dramatic classes and to overcome potential obstacles during the field study.

\section{Study Population and Sample}

The study population consist of the $6^{\text {th }}$ graders in the schools of the Karak Education Directorate in the $2^{\text {nd }}$ semester of the academic year 2019/2020. Targeted schools have 4 sections of the $6^{\text {th }}$ grade students with a total number of (140) students, (68) males and (72) females.

A random sample of (70) students was selected from the study population. The sample was divided into two groups: total of (35) students in the experimental group and (35) students in the control group.

\section{Instruments and Data Collection}

Two data collection instruments were employed, including:

1) Achievement test of English language speaking skill; the pre-test and post-test consisted of (13) questions with 25 maximum scores, which helps to measure students' level before and after being exposed to the drama classes.

2) The attitude questionnaire: it is a self-completed questionnaire aims at measuring students' attitude toward learning English language. The questionnaire consisted of (35) items distributed over four main domains, as shown in the table (1).

Table (1): Attitude Questionnaire :Domains and Items.

\begin{tabular}{clc}
\hline Number & \multicolumn{1}{c}{ Domain } & Items \\
\hline $\mathbf{1}$ & General attitudes towards learning the English language. & $(1-10)$ \\
$\mathbf{2}$ & Attitudes toward English language teachers. & $(11-18)$ \\
$\mathbf{3}$ & Attitudes toward the employed English teaching methods. & $(19-25)$ \\
$\mathbf{4}$ & Attitudes toward the textbook. & $(26-35)$ \\
\hline
\end{tabular}

The questionnaires based on five-point-Likert instrument ranging (1: Strongly Disagree; 2: Disagree; 3: Neutral; 4: Agree, and 5: Strongly Agree). The developed questionnaire translated to Arabic as the primary language of the student is the Arabic (Appendix B). It consisted of (4) domains as previously shown in table (1).

\section{Validity and Reliability of Drama performance Test}

To verify the content validity of the study instruments, they were sent to a panel of academics and experts in teaching instructions and EFL education for assessment. The tests were approved, with minor 
modifications were made by them. In other words, they found the tests valid for sixth-grade elementary students.

As for the reliability of designed test, the method of test and re-test was employed to ensure that there are no significant differences between different periods when applying the same test. To achieve this, the same test was applied in different times with interval period of two weeks. Afterwards, the PearsonCorrelation test was applied between the results, which indicated a high correlation between the results of test and retest of pre-test and post-test, as shown in table (2).

Table(2) . Pearson correlations between study's instruments

Pearson Correlation

Pearson Correlation

Achievement Test

Achievement Retest

Attitude Test

Attitude Retest

$0.88^{* *}$

$0.87^{* *}$

Results in table (2) indicates a high degree of reliability of the study's instruments, which proves the internal consistency for both instruments, achievement test, and attitudes measurement scale.

\section{Validity and Reliability of Attitude Questionnaire \\ Questionnaire's Validity}

To validate the content of the student attitude questionnaire toward English learning, it was sent to a panel of academics and experts in teaching instructions and specialists in EFL education for their opinion and comments. Afterwards, upon receiving their responses, it was found that they suggested to remove, added and modify some items. As a result, all their suggestions, modifications, amendments were duly followed to have the final draft of instruments.

\section{Questionnaire's Reliability}

In addition to the results of test and re-test results in table (3), reliability test requires the instrument to provide the same results, even after 100 trials, with a tolerated error not exceeding (5\%). Therefore, Cronbach's alpha reliability test was applied to (30) respondents representing the pilot sample of the target population. Table (3) shows Cronbach's alpha coefficients.

Table (3) Reliability Test for Attitude instrument

\begin{tabular}{lc}
\hline \multicolumn{1}{c}{ Attitude } & Cronbach's $\boldsymbol{\alpha}$ \\
\hline General attitudes towards learning English language. & 0.81 \\
Attitudes toward English language teachers. & 0.87 \\
Attitudes toward the employed English teaching methods. & 0.90 \\
Attitudes toward the textbook. & 0.88 \\
\hline
\end{tabular}

The values of Cronbach's $\alpha$ for all attitudes toward English teaching ranged from 0.81 to 0.90 , which confirms an acceptable level of reliability according to (Sekaran, 2016).

\section{Results and Discussion}

Results of the Study's First Question; Are there statistically significant differences at the level of $(\alpha=\leq 0.05)$ in the development of the sixth-grade students' speaking skill attributed to the teaching method (drama, conventional)?

A total of (70) cases were considered for both descriptive and analytical processing. Students were divided into two equal groups: control and experimental. Each group included (35) students; the control group was taught by using conventional teaching method, while the experimental group was taught using drama method. Therefore, this study involves the $6^{\text {th }}$ graders attending pre-test and then a post-test after the implementation of drama classes, as positive effects were expected following the dramatic teaching intervention. The results of the pre-test and the post-test are shown in the Table (4). 
Table (4) Pre-test \& Post-Test Results of Control and Experimental Groups

\begin{tabular}{ccc}
\hline \multirow{2}{*}{ Group } & \multicolumn{2}{c}{ Students' Mean score out of (25) } \\
\cline { 2 - 3 } & Pre-Test Means & Post-Test Means \\
\hline Control & 14.22 & 14.59 \\
Experimental & 14.39 & 17.77 \\
\hline
\end{tabular}

The results in Table (4) show slight apparent differences between the two groups before the drama class intervention was performed. This slight difference indicates that the two groups have the same level of achievement in EFL classes; also, it supports the validity of undertaking the intended intervention. In contrary, results show a remarkable difference between the two groups after performing the drama class intervention. This difference indicates that the two groups have a different level of achievement in EFL classes; also, it supports the expected potential effect of the educational drama intervention undertaken.

Furthermore, T-test for independent sample was employed to investigate the significance of the difference as shown in the Table (5).

Table (6): T-test for independent samples for the results of Pre-Test and Post-Test

\begin{tabular}{|c|c|c|c|c|c|c|c|c|c|}
\hline & & \multirow{3}{*}{$\begin{array}{c}\text { Mean } \\
\text { Difference }\end{array}$} & \multirow{3}{*}{$\begin{array}{l}\text { Std. Error } \\
\text { Difference }\end{array}$} & \multirow{2}{*}{\multicolumn{2}{|c|}{$\begin{array}{l}95 \% \text { Confidence } \\
\text { Interval of the } \\
\text { Difference }\end{array}$}} & \multirow{3}{*}{$\mathbf{F}$} & \multirow{3}{*}{$T$} & \multirow{3}{*}{ DF } & \multirow{3}{*}{$\begin{array}{l}\text { Sig.(2- } \\
\text { tailed) }\end{array}$} \\
\hline & & & & & & & & & \\
\hline & & & & Lower & Upper & & & & \\
\hline $\begin{array}{c}\text { Equal } \\
\text { variances }\end{array}$ & $\begin{array}{l}\text { Pre- } \\
\text { Test }\end{array}$ & -.163 & 1.674 & -3.504 & 3.178 & .009 & -.09 & 68 & .923 \\
\hline assumed & $\begin{array}{l}\text { Post- } \\
\text { Test }\end{array}$ & 3.1914 & 1.53352 & -6.25 & -.131 & 4.55 & 2.08 & & $.041^{*}$ \\
\hline
\end{tabular}

*Significant at level $(\alpha=\leq 0.05)$.

Regarding the Pre-Test, the results in Table (5) indicate no significant differences at the level $(\alpha=\leq 0.05)$ between control and experimental group. This confirms the validity of the procedures to start the drama classes' intervention in the next step. Whereas regarding the Post-Test results indicate a significant difference at the level $(\alpha=\leq 0.05)$ between the two groups in favour of the experimental group. This confirms that drama classes can make a positive difference in student achievement.

Results of the Study's Second Question; Are there statistically significant differences at the level of $(<=0.05)$ in the development of speaking skill attributed to the variable of student gender (males, females)?

For the study's second question, the independent t-test was employed, and the results shown in the Tables (6) and (7) respectively.

Table (6) Student Gender Group Statistics

\begin{tabular}{cccccc}
\hline & Gender & N & Mean & Std. Deviation & Std. Error Mean \\
\hline Posttest & M & 35 & 15.32 & 1.30 & 0.06 \\
& F & 35 & 17.77 & 1.80 & 0.15 \\
\hline
\end{tabular}

Results in Table (6) revealed apparent differences between the mean scores of the students germane to the variable of gender in favor of female students. Furthermore, to investigate whether these differences are statistically significant further analysis was conducted and the results as shown in the Table (7) indicate no statistical differences in the development of English-speaking skill between students at the level of $(\alpha=\leq 0.05)$ that could be attributed to the variable of gender. This can be justified as students learn English, in the same way, using the same textbox and within the same teaching environment. 
Table (7) Differences in the development of speaking skill attributed to the student gender

\begin{tabular}{|c|c|c|c|c|c|c|}
\hline & $\mathbf{F}$ & $\mathrm{T}$ & df & $\begin{array}{l}\text { Sig. (2- } \\
\text { tailed) }\end{array}$ & $\begin{array}{c}\text { Mean } \\
\text { Difference }\end{array}$ & $\begin{array}{l}\text { Std. Error } \\
\text { Difference }\end{array}$ \\
\hline $\begin{array}{l}\text { Equal } \\
\text { variances } \\
\text { assumed }\end{array}$ & .926 & 1.08 & 68 & .281 & 1.71 & 1.568 \\
\hline
\end{tabular}

Results of the Study's Third Question: Are there statistically significant differences at the level of $(\alpha=\leq 0.05)$ in developing the attitude of the 6th graders toward learning English that could be attributed to the variable of teaching method (drama, conventional)?

This section describes the responses to the students' attitude questionnaire towards English language learning. Their attitudes were ranked into three categories (Hight, Moderate and Low) based on their responses to the five-point Likert scale's weight descriptors.

The table (8) shows the overall results of student's attitudes of all dominions.

Table (8) Students' Attitudes toward English learning.

\begin{tabular}{|c|c|c|c|c|}
\hline $\mathbf{N}$ & Domain & Mean & Std.D & Degree \\
\hline 1 & $\begin{array}{l}\text { General attitudes towards learning English } \\
\text { language. }\end{array}$ & 3.70 & 0.69 & High \\
\hline 2 & Attitudes toward English language teachers. & 3.87 & 0.56 & High \\
\hline 3 & $\begin{array}{l}\text { Attitudes toward the employed English } \\
\text { teaching methods. }\end{array}$ & 4.02 & 0.89 & High \\
\hline 4 & $\begin{array}{l}\text { Attitudes toward the English language } \\
\text { textbook. }\end{array}$ & 3.86 & .089 & High \\
\hline & Overall Mean & \multicolumn{2}{|c|}{3.86} & High \\
\hline
\end{tabular}

The Table (8) shows a high level of positive attitudes among $6^{\text {th }}$ graders towards learning English as a foreign language with overall mean score of (3.86), more interestingly, results revealed that the domain of teaching method occupied the first rank in effecting positively the students' attitudes toward learning English with mean score

of (4.02), while the second rank was occupied by the factors related to the domains of teacher and those related to the textbook with the mean scores of (3.87 and 3.86) respectively. The fourth and last rank was occupied by the factors related to students' general feelings toward learning English language.

Results related to the study's third question, which stated; Are there statistically significant differences at the level of $(\alpha=\leq 0.05)$ in developing the attitudes of the sixth-graders toward learning English that could be attributed to the variables of student gender (male and female) or to the variable of teaching method (drama, conventional)?

For the purpose of this questions, the means scores, and the independent t-test were employed and calculated, the results were as shown in the Tables (9) and (10) respectively. 
Table (9). Mean Scores of Students' Attitudes Toward English Learning According to the gender and teaching methods

\begin{tabular}{cccccc}
\hline \multicolumn{1}{c}{ Variables } & & $\mathbf{N}$ & Mean & Std. Deviation & Std. Error Mean \\
\hline Variable of Students' & Male & 35 & 3.8568 & .55217 & .09333 \\
Gender & Female & 35 & 3.8660 & .48399 & .08181 \\
Variable of Teaching & Conventional & 35 & 3.4501 & .42690 & .07216 \\
Method & Drama & 35 & 4.2727 & .09312 & .01574 \\
\hline
\end{tabular}

As presented in the Table (9), and regarding the variable of students' gender, results indicate slight differences between the two groups, however these differences, as shown in the Table (10) were not statistically significant. Whereas, regarding the variable of teaching method, results revealed that there are apparent differences, and more interestingly, as shown in the Table (10),

Table (10) The Independent T-Test Differences in the attitudes toward learning English that is Attributed to the Variable of Teaching Method

\begin{tabular}{|c|c|c|c|c|c|c|c|}
\hline & & $\begin{array}{c}\text { Mean } \\
\text { Difference }\end{array}$ & $\begin{array}{l}\text { Std. Error } \\
\text { Difference }\end{array}$ & F & $\mathrm{T}$ & DF & $\begin{array}{l}\text { Sig.(2- } \\
\text { tailed) }\end{array}$ \\
\hline \multirow{2}{*}{$\begin{array}{l}\text { Equal } \\
\text { variances } \\
\text { assumed }\end{array}$} & $\begin{array}{l}\text { Variable of } \\
\text { Teaching } \\
\text { Methods }\end{array}$ & .82259 & .07386 & 40.68 & 11.13 & & $.000^{*}$ \\
\hline & $\begin{array}{c}\text { Variable of } \\
\text { Gender }\end{array}$ & -.00927 & .12411 & .035 & .075 & 68 & .941 \\
\hline
\end{tabular}

*Significant at level $(\alpha=\leq 0.05)$.

these differences are statistically significant with $\mathrm{F}$ value of (40.684) and significance value of (.000) in favor of the experimental group. Which in turn means that students' attitudes toward learning English language was more positive for those who taught by using the drama teaching method.

\section{DISCUSSION}

Discussing results related the effect of the Drama teaching strategy on the $6^{\text {th }}$ graders speaking skills and on their attitudes toward learning English language.

Results of the current study show that the use of dram activities opens an opportunity to support English language speaking skills as being effective teaching strategy compared to the conventional one. After the experiment, $6^{\text {th }}$-graders prove better English language speaking skills and increased motivation towards English language speaking skills learning and acquisition. In addition, results confirm that students develop a positive attitude towards English language speaking skills evidenced by the post-test results and their attitudes toward English language speaking skills when using drama activities compared to the conventional teaching strategies. It has been found that the adoption of drama lessons has a positive effect on students' academic performance and English learning attitudes. In this study, the findings highlight the attributes that make the adoption of drama lessons in English language speaking skills one of the most promising teaching approaches that allow students to develop a positive attitude toward English learning.

The results confirm that the use of dram dynamically helps students to practice and master English language speaking skills in a way that depends upon casting and encourages smooth learning of English language. This result agrees with several studies (Kauts, 2016; Masoumi-Moghaddam, 2018; Susanti, 2019), which argue that the more active and interactive the Learning experience, the more likely students will improve their speaking skills. In addition, dram strategy reinforces the student's positive attitude toward the importance of learning English language. The evidence emerges from the questionnaire confirm that students emphasize that the dram motivate them to practice English language speaking skills. Thus, students support the idea that the use of drama strategy improves their English language speaking skills and highly involved using this experience for its advantages in helping students develop their English language skills. The current positive attitude among the $6^{\text {th }}$ grader's students toward using drama strategy can be 
similarly supported by previous studies (Janudom and Wasanasomsithi, 2009; Rabab'a, 2015; Sarmento \& Messac, 2017).

To sum up, the positive effect of drama strategy can be seen in the results of students' academic achievement in the post-test and the developed attitudes questionnaire. A sense of satisfaction provided by drama activities motivates students to have the experience themselves, at home, in their free time and to spend more time in speaking English, which helps students improve their cognitive. Furthermore, results affirmed that teachers should be inspired to create English learning activities that make the class interesting and motivating. This can help students to enjoy EFL learning instead of feeling bored when they must go through the same things repeatedly, no matter how consistently the method is used. More interestingly, these results align with the constructivist theory, which is approved in the case of using dram learning environments. These results align with several studies, in a different context, which ensured the benefits of dram activities (Al-Sharary, 2019; Sarmento, \& Messac, 2017).

\section{Discussing results related the effect of the gender on the $6^{\text {th }}$ graders speaking skills and on their attitudes toward learning English language.}

Based on the variable of gender, results revealed that there are slight differences between female and male students on their speaking skills and their attitudes toward learning English learning. Furthermore, results confirm that their no statistically significant differences between $6^{\text {th }}$ graders students in developing their English-speaking skills and attitudes attributed to gender. This refers to the fact that all students are taught by the same teaching method and within the same learning environment. In link to that, within the drama learning context all students, females, or males, allowed to play the role as actors or audience to follow up the drama story and activities at a same level of interest. Females or male's response in acting or interacting with drama activities as they enjoy and feel more comfortable when drama involved in preparing the lesson plans. In addition, female and male students trained by the same teacher, who became close to them and familiars with her/him during the experiment. Therefore, having dram activities empower students' learning process and improve their English language speaking skills regardless of their gender. Finally, it is expected that the adopted textbook was prepared by educational experts, who carefully avoid having negative implications to acquire knowledge related to gender or other socio-demographic variables. The same result has been drawn by (Rahman, 2010; Kauts, 2016).

\section{Conclusion}

The results of the current study indicate that using drama as a tool rather than an end gains importance in teaching a foreign language. In addition, the results show that the use of drama activities opens the opportunity to support English language speaking skills with advantages over conventional teaching patterns. Results confirm that students develop a positive attitude when adopting drama classes and can improve their academic performance in the English language, in general, and in speaking skills in particular without any connection with their gender.

Perhaps one of the conclusions, through direct observations of the researchers, where it is expected that the greatest advantages to being gained from the use of drama are that students become more confident in their use of English by experiencing the language in operation (learning by practice).

More interestingly, it can be concluded that the student-centeredness, inherent in all dramatic activities, as expected, improves students' motivation and attitudes toward learning a foreign language, particularly that students are physically involved in the drama along with the concept of learning language through action, which in turn is an effective learning process. Therefore, the use of drama seems to be an effective teaching strategy that English language teachers can rely on.

To sum up, If drama is considered as a teaching method in the sense of being part of the eclectic approach to English language teaching, then it can become a main aid in the acquisition of speaking skill(s), bearing in mind that drama is expected to encourage adaptability, fluency, and communicative competence.

\section{Recommendations}

\section{The current study proposes the following recommendations:}

1. Developing and adopting drama activities to help students improve their speaking skills.

2. Dramatic activities should be integrated into the English Language textbooks. 
3. Provide training for EFL teachers to acquire the necessary skills for the optimal application of drama reaching strategy.

4. Further studies should be conducted to investigate the effect of using drama, as a teaching strategy, for teaching subjects other than the English language.

5. Ministry of Education, in Jordan, is required to continue its efforts and endeavors in training teachers on how to teach using drama in their classes.

\section{REFERENCES}

Ali, N. (2008). Drama and mathematical thinking skills of kindergarten children. The World of Books. Cairo.

Ali, S. (2012). The effect of using drama on developing English-speaking skill among primary school learners. Educational and social studies, Egypt, 10, (4): 61-73.

Al-Jamal, Dina and Al-Jamal, Ghadeer (2014) An Investigation of the difficulties faced by EFL undergraduates in speaking skills. English Language Teaching 7 (1), 19-27.

Al-Sharary, F. (2019) The impact of using the educational drama strategy in developing speaking skills on English Language among the first year intermediate students. Umm Al-Qura University Journal for Educational and Psychological Sciences - (11) - (1).

Attia, T. (2015). The effectiveness of the dialogue drama strategy in developing some oral communication skills among students of the Arabic language who are not speaking it. Educational Journal, Egypt, 41, 1-35.

Chaney, A. \& Burk, T. (1998). Teaching oral communication in grades K-8. Boston: Allyn \& Bacon.

Duman,T. \& Karagöz, S. (2016).An evaluation of Turkish teacher education system compared to other models in different countries. International Journal of Educational Research Review,1(1),1-13.

Helwa, H. S. (2015). Using puppets based learning for promoting primary stage pupils EFL listening and speaking skills. Unpublished Master Thesis, Banha University, Egypt.

Holden, S. (1981). Drama Language Teaching. Handbook for language teachers. Longman Group. London, 1981.

Janudom, R. \& Wasanasomsithi, P. (2009). Drama and questioning techniques: powerful tools for the enhancement of students' speaking abilities and positive attitudes towards EFL Learning. ESP World Issue, 5 (26), 8.

Kalogirou, K., Beauchamp, G., \& Whyte, S. (2019). Vocabulary acquisition via drama: Welsh as a second language in the primary school setting. The Language Learning Journal, 47(3), 332-343.

Karagöz,S. \& Rüzgar,M.E. (2020). The observations of student teachers in regard to professional qualifications of advisor teachers during teaching practicum. International Journal of Educational Research Review,5(2),141-150.

Kauts, A. (2016), Effect of dramatization on speaking skills and academic achievement in English among primary students. MIER Journal of Educational Studies, Trends and Practices, 3(2),

Maiullo, J. (2018). Radio drama for speaking practice. English. Teaching Forum, 56, (2). 16-25.

Masoumi-Moghaddam, S. (2018). Using drama and drama techniques to teach English conversations to English as foreign language learners. International Journal of Applied Linguistics and English Literature, 7(6), 63-68.

Moore, Mandie M. (2004) Using Drama as an Effective Method to Teach Elementary Students. Senior Honors Theses, Honors College, Eastern Michigan University, USA.

Nassar, M. (2000). Educational drama theory and application. Amman: National Center for Publishing and Distribution.

Rabab'a, I. (2015). The impact of using educational drama for learning the speaking skill (oral expression) and improving achievement to students of ( $A S O L$ ). Unpublished M.A. Thesis, University of Jordan, Amman, Jordan.

Rahman, M. M. (2010). Teaching oral communication skills: A task-based approach. ESP world, 9(1), 1-11.

Revathy, M., \& Ravindran, K. (2016). Enhancing effective speaking skills through role-play and tongue twisters. Language in India, 16(9).

Sarmento, J. A., \& Messac, S. (2017). Using dram to develop students' speaking skills to the second-grade students of Escola Teknico Professional OE-CUSSE. ISCE. Journal of Innovative Studies on Character and Education, 1(1), 46-67.

Shameem, Ahmed (2015) Attitudes towards English Language Learning among EFL Learners at UMSKAL. Journal of Education and Practice, 6, (18), 6-16.

Susanti, S. (2019). Drama performance to increase students' practical English for daily conversation. in SNPMas: Seminar Nasional Pengabdian pada Masyarakat, (pp. 184-191). 